\title{
AEACUS.
}

\section{UEBER DIE IN'TERPOLATIONEN}

IN DEN

ROEMISCHEN DICHTERN.

MIT

BESONDERER RUECKSICH'T AUF HORAZ.

VON

O. F. GRUPPE.

B E R L I N

DRUCK UND VERLAG VON G. REIMER.

1872. 
